\title{
Figure S2
}

A

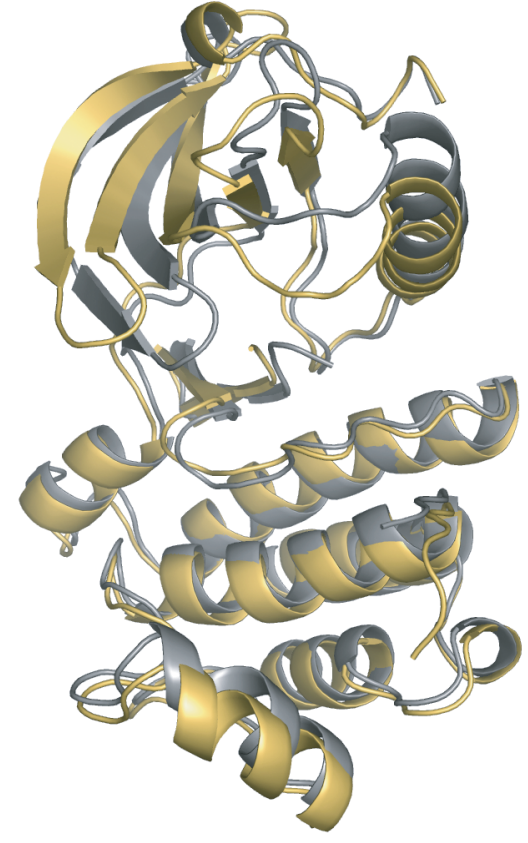

Abl simulation (200 ps)

Abl Molecule B

B From top to bottom: restraint force vs. time, r.m.s. deviation vs. time for two simulations (force constant $\mathrm{K}=10.5 \mathrm{pN} / \AA$ ) ).

i) No DFG flip occurs
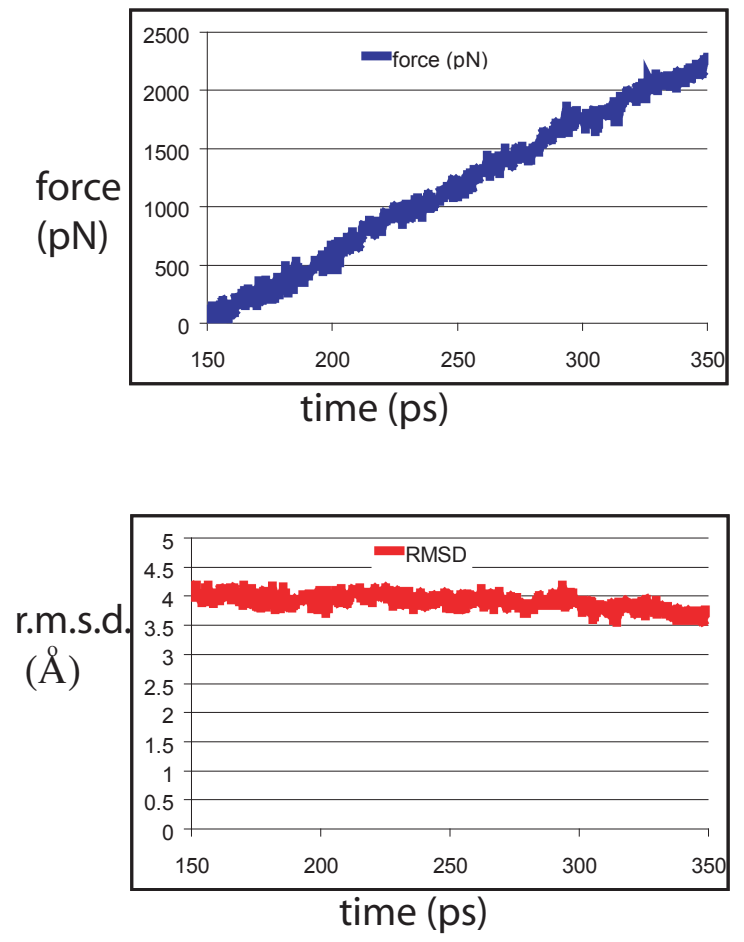

ii)Partial DFG flip occurs
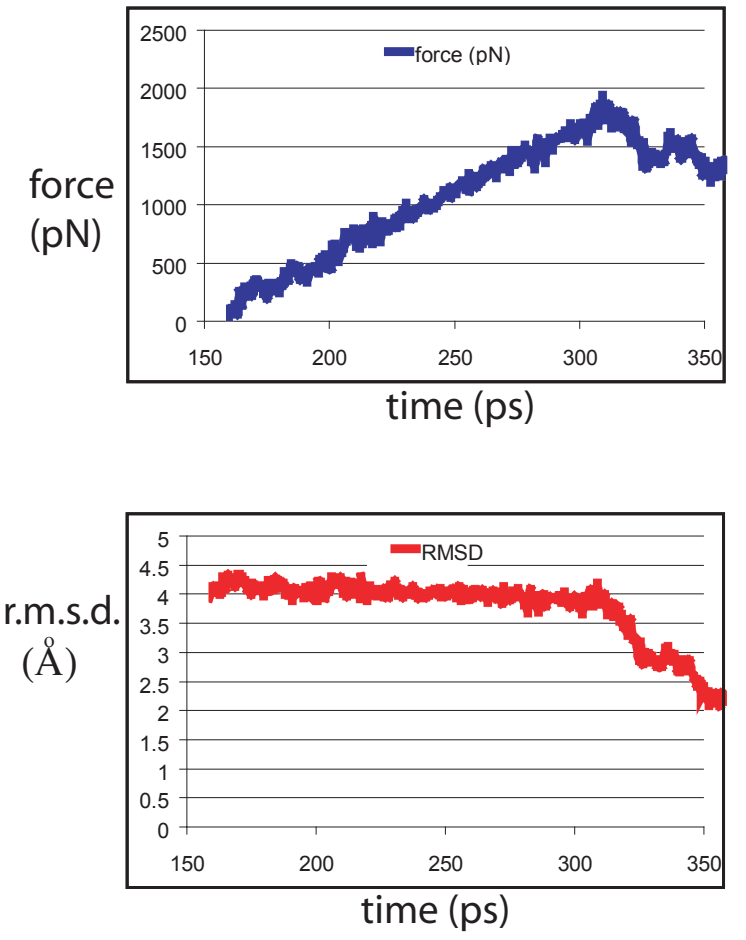